\title{
Metastatic Spinal Cord Compression: Unraveling the Diagnostic and Therapeutic Challenges
}

\author{
STERGIOS BOUSSIOS ${ }^{1}$, DEIRDRE COOKE $^{1}$, CATHERINE HAYWARD $^{1}$, \\ FOIVOS S. KANELLOS ${ }^{2}$, ALEXANDROS K. TSIOURIS ${ }^{2}$, AIKATERINI A. CHATZIANTONIOU ${ }^{3}$, \\ NIKOLAOS ZAKYNTHINAKIS-KYRIAKOU ${ }^{4}$ and AFRODITI KARATHANASI ${ }^{1}$ \\ ${ }^{1}$ Acute Oncology Assessment Unit, Medway NHS Foundation Trust, Kent, U.K.; \\ ${ }^{2}$ Department of Biological Applications \& Technology, University of Ioannina, Ioannina, Greece; \\ ${ }^{3}$ Faculty of Medicine, University of Ioannina, Ioannina, Greece; \\ ${ }^{4}$ Leicester Diabetes Research Centre, Leicester, U.K.
}

\begin{abstract}
Malignant spinal cord compression (MSCC) is one of the most devastating complications of cancer. Patients often present with a history of progressive pain, paralysis, sensory loss, progressive spinal deformity, and loss of sphincter control. It is an emergency that requires rapid decision making on the part of several specialists, given the risk of permanent spinal cord injury or death. The goals of treatment in spinal metastases are pain control and improvement of neurological function in order to achieve better quality of life $(Q o L)$. The standard of care in most cases is rapid initiation of corticosteroids in combination with either surgical decompression in case of an operable candidate, followed by radiation therapy $(R T)$ or $R T$ alone. Surgery is associated with improved outcomes, but is not appropriate for many patients presenting with advanced symptoms of MSCC, such as paralysis, or those with a poor performance status, or cachexic state, as well as altered mental conditions, comorbidities, surgical risks, and limited life expectancy. On the other hand, aggressive surgical treatment and post-operative $R T$ is advocated for those with more favorable prognosis, or who are expected to have higher neurological recovery potential. Many candidates may require for combined anterior
\end{abstract}

This article is freely accessible online.

Correspondence to: Dr. Stergios Boussios, MD, Ph.D., Consultant Medical Oncologist, Medway NHS Foundation Trust, Windmill Road, Gillingham, Kent, ME7 5NY, U.K. Tel: +30 6938625210 and +447960382149, e-mail: stergiosboussios@gmail.com and stergios.boussios@nhs.net

Key Words: Metastatic spinal cord compression, corticosteroids, decompressive surgery, palliative radiotherapy, radiosurgery, rehabilitation, review. and posterior approaches to effectively deal with the compressive pathology and stabilize the spine. Most patients are presently treated by primary $R T$, given with the aim of improving function and symptom management. However, there is still debate regarding the most appropriate RT schedule. Rehabilitation can serve to relieve symptoms, QoL, enhance functional independence, and prevent further complications. Ambulatory status has been found to be an important prognostic factor for patients with MSCC.

Spine is the most common osseous site for metastatic disease, due to the inherent rich vascular supply and extensive lymphatic drainage (1). Spinal tumors are categorized into extradural tumors, intradural extramedullary tumors and intradural intramedullary tumors. Malignant spinal cord compression (MSCC) is defined as compression of the spinal cord or cord equina by metastatic or direct spread to the vertebrae that may cause neurological disability (2). It occurs in up to $5 \%$ of all patients with cancer; however, it is a feature of advanced cancer, most commonly seen in patients with cancers of the breast, lung and prostate, which comprise $60 \%$ of cases (3). Furthermore, MSCC represents the initial manifestation of malignancy in up to $20 \%$ of cases (3). The incidence is likely to increase alongside with improved cancer survival rates (4).

The consequences of MSCC range from pain and paresthesia, to motor weakness, loss of sphincter control, and paraplegia. The median time from pain onset to MSCC diagnosis is about 2 months (5). These findings have an insidious course and therefore diagnosis of MSCC can often be delayed. The investigation that definitely establishes diagnosis is imaging and, magnetic resonance imaging (MRI) - preferably with gadolinium - is the most sensitive scan. Clinical outcomes, in terms of preservation of function, 
are closely linked to the promptness of diagnosis and treatment, with full recovery after the onset of motor symptoms relatively rare (6).

Consultation with medical oncology, radiation oncology, and neurosurgery is imperative in order to facilitate a multidisciplinary approach. The intent of treatment for MSCC is usually palliative focusing on reducing pain and/or restoring or preserving physical and neurological function. There are a variety of therapeutic options, which mainly depend on prognosis prediction, neurological state and recovery potential. Once the diagnosis of MSCC is suspected, patients with neurological deficits should receive prompt administration of dexamethasone. Local management strategies generally include palliative RT, or surgical posterior decompression with or without instrumentation or total en bloc spondylectomy (7-9). Single-stage posterolateral transpedicular corpectomy and fusion has been described as well to treat vertebral body disease in the thoracolumbar spine $(10,11)$. The optimal palliative RT alone is usually adapted for those with limited neurological recovery potential and poor overall estimated survival. Radiosurgery techniques which deliver intense focal irradiation to a delimited area with imaging guidance have recently emerged as increasing effective treatments in MSCC, especially in radioresistant tumors. Interestingly enough, stereotactic radiosurgery (SRS) and different radiation technologies have been studied in recent clinical trials. Finally, it is important to consider rehabilitation in patients with MSCC, notwithstanding diminished life expectancy.

\section{Literature Review}

This article reviews the literature for studies on MSCC. Publications between October 1980 and February 2018 were eligible for inclusion. Original papers, review articles and case reports were included. Language restrictions were not used. We also searched registers of clinical trials, and abstracts of scientific meetings. The results were screened in a non-blinded fashion based on the title and abstract, excluding all papers not related to MSCC. Bibliographies of acceptable papers were reviewed to identify any other papers that may have been missed by the search criteria.

Epidemiology and pathophysiology. More than 20,000 MSCC new cases are diagnosed annually in the USA (12). This condition may cause permanent paralysis based on sensory deficits and sphincter disturbances, and increase mortality due to immobility and the relevant risk of skin breakdown, venous thromboembolism, sepsis, and pneumonia (13). The true incidence of MSCC is unknown and probably underestimated by at least $15 \%$, as the detection rate depends on admission to hospital, and correct diagnosis (14). Post mortem evidence indicates that it affects approximately $5-14 \%$ of patients with solid tumors. It is likely that the incidence of MSCC will increase in the future due to improved cancer treatments resulting in better survival and outcomes.

The median age of MSCC diagnosis is 65 years (14). It is reported that approximately $80 \%$ of those patients had an established diagnosis of cancer whereas $20 \%$ presented with MSCC as the first presentation of malignancy (3). Lung, breast and prostate cancers account for over $60 \%$ of MSCC cases (3), whereas $7 \%$ of patients have unidentified site of primary tumour (15). Lumbar spine seems most frequently involved, followed by the thoracic and cervical segments; nevertheless, clinically symptomatic spinal metastases are most often localized to the thoracic spine, followed by the lumbar and cervical segments (16). The majority of MSCC patients die within the first year following diagnosis (12). Several mechanisms are involved in the development of MSCC. The commonest is haematogenous spread to the vertebral spine, where the tumor cells find a hospitable environment in the bone marrow. Bony destruction and expansion of the tumor then cause collapse and compression of the dural sac, root sleeves, and their contents, which lead to vascular compromise, vasogenic edema, and demyelination (16). This deformity results in spinal instability by increasing strain on the support elements of the spine including muscles, tendons, ligaments and joint capsules (17). If the MSCC is of recent onset with some preservation of neurological function, the effects are often reversible. In contrast, recovery is unlikely when, vascular injury causes infarction of the spinal cord, typically after prolonged compression (18). Slow onset compression allows cord adaptation and predicts a relatively favorable outcome as compared to sudden onset. Direct leptomeningeal extension is less frequent (19). Metastatic disease is thought to reach the leptomeninges through hematogenous spread, direct extension, and cerebrospinal fluid (CSF) seeding. Indeed, drop metastasis is based on tumor cells transport by the CSF which become entangled among the roots of the cauda equina (16).

Diagnosis. Patients with suspected spine or spinal column involvement require a thorough diagnostic work up. History, physical examination, and imaging are undertaken to establish a diagnosis and provide the basis for assessing management options and formulating treatment strategies. Back pain is the earliest and most compelling manifestation of MSCC and over $95 \%$ of patients have the symptom at the time of diagnosis (20). The duration of pain is variable and may be present for weeks or months, accompanied by neck pain, followed by weakness, sensory loss, and sphincters dysfunction (16). Physical examination should include an assessment of strength, sensation, reflexes and sphincter function. 
In the past, myelography has been the gold standard for localizing the level of spinal cord or nerve root compromise, but it still remains a valuable imaging tool, particularly for patients who are unable or unfit to undergo MRI (16). Analysis of a myelographic block can detect the anatomic location of an offending lesion. The study is optimized when it is followed by axial computed tomography (CT) to demonstrate the area of interest in transverse sections. Myelography also offers the benefit of providing potential cytologic diagnosis from CSF.

CT provides highly detailed imaging of the osseous anatomy of the spine and degree of tumor involvement, with a reported sensitivity and specificity of $66 \%$ and $99 \%$, respectively (16). As plain CT lacks the sensitivity to distinguish soft tissue boundaries, the demonstration of dural sac and root sleeve displacements can be enhanced with its use in conjunction with myelography. MRI has become the imaging modality of choice for spine pathologic changes, including metastatic tumors (16). Indeed, gadoliniumenhanced MRI offers sensitivity and specificity of $93 \%$ and $98 \%$, respectively. In addition, it provides anatomic details about leptomeningeal involvement, and soft tissue structures in the spine, including the intervertebral discs, spinal cord, spinal nerve roots, spinal musculature and ligaments (21). Diffusion-weighted images distinguish osteoporotic vertebral fractures which are hypointense, from metastatic being demonstrated hyperintense. Metastases enhance with gadolinium similarly to normal bone marrow and may merely appear isointense after contrast administration. Post contrast fat-suppressed images differentiate metastases from bone marrow in this setting (16). Due to the fact that multiple sites of metastasis exist in almost one-third of patients, it is hugely important to image the entire spine $(19,22)$.

Finally, percutaneous biopsy of the spine was first introduced 70 years ago, and currently is supported by improved imaging capabilities and instrumentation with an achieved overall success rate of 80 to $95 \%$. This technique is indicated to establish a tissue diagnosis for a spinal lesion in a cancer patient, particularly when RT may be the initial treatment of choice, thereby obviating the necessity for surgical exploration. Percutaneous spine biopsy may help to distinguish between a metabolic and a neoplastic cause for a pathologic fracture of the spine and to differentiate between an infective and a neoplastic process (16).

Signs and symptoms. Permanent neurological damage can be prevented by early diagnosis and treatment. Identification of symptoms and signs related to the diagnosis of MSCC is critical, in order to determine the patients who should be referred for imaging. Pain characteristics that better predict MSCC include localisation in the upper or mid spine, progressive discomfort, severity and aggravation by activities that increase the pressure within the spinal canal. The pain may be localized, mechanical and radicular pain. Localized pain is the result of periosteal stretching and inflammation caused by tumor growth. It is often nocturnal and could be improved with activity and anti-inflammatory medications (23). Mechanical pain is suggestive of impending or established spinal instability, and typically occurs with transitional movements, lying prone or supine. It is managed with stabilization of the spine with bracing or surgical fixation, whereas is often refractory to anti-inflammatory medications $(17,24)$. Radicular pain may be developed due to nerve root compression by the tumour or secondary to vertebral collapse and, is usually followed by motor, and sensory symptoms as well as bladder dysfunction. This sequence of symptoms is probably related to the fact that motor tracts may be functionally more sensitive to compression of the cord than the sensory tracts (25). Heaviness or clumsiness of limbs represent an early sign of motor deficits whereas, sensory deficits include anaesthesia, hyperaesthesia, or paraesthesia. Motor weakness may be either upper or, lower motor neuron or even a combination of both depending on the area of the cord involved (17). The pattern of sensory impairment is determined by the implicated spinal pathway. Involvement of the lateral spinothalamic tract reduces pain and temperature perception on the contralateral side of the body, but rarely results in paresthesias. Overall, autonomic symptoms with bowel and bladder dysfunction, loss of sweating below the lesion and orthostatic hypotension, are associated with a poorer prognosis.

Treatment. Treatment for MSCC occurs once diagnosis is confirmed ideally with an MRI. Pre-treatment ambulatory status has consistently been shown to be the most important factor in determining treatment response (20). Treatment options include corticosteroids, surgical intervention, RT, bisphosphonate therapy, and chemotherapy. The aim of the implementation of steroids is the prevention of further neurological decline, preservation of spinal stability, and achievement of pain relief (22). In certain situations steroids may directly decrease tumor size, which is the source of compression. Following initiation of high-dose steroids, patients are stratified for treatment with a combination of RT with or without surgery, depending on factors such as performance status, extent of visceral and skeletal disease, inherent tumor radiosensitivity, treatment history, neurological status and pain intensity (13). If there is uncertainty regarding spinal stability, surgical spinal stabilization should precede RT. Anticoagulation and hyperbaric oxygen occasionally stabilize or even improve symptoms, whereas bevacizumab has shown benefit anecdotally (24). Table I depicts the reported in the literature MSCC case series, including details of treatment, and its associated complications, as well as outcomes. 
Table I. Case Series of patients with MSCC reported in the literature.

\begin{tabular}{|c|c|c|c|c|c|c|}
\hline $\begin{array}{l}\text { References and } \\
\text { date of publication }\end{array}$ & $\begin{array}{c}\text { Study } \\
\text { type }\end{array}$ & $\begin{array}{c}\text { Number of } \\
\text { patients }\end{array}$ & $\begin{array}{l}\text { Steroid } \\
\text { regimen }\end{array}$ & $\begin{array}{l}\mathrm{RT} \text { regimen and/or } \\
\text { surgical procedure }\end{array}$ & Findings & $\begin{array}{l}\text { Side } \\
\text { effects }\end{array}$ \\
\hline $\begin{array}{l}\text { Sorensen PS et al. } \\
(27), 1994\end{array}$ & $\begin{array}{l}\text { Retrospective } \\
\text { study }\end{array}$ & 57 & $\begin{array}{l}96 \mathrm{mg} \text { IV bolus then } \\
96 \mathrm{mg} \text { PO ( } 24 \mathrm{mg} \text { QID) } \\
\text { weaned over } 14 \text { days }\end{array}$ & $\begin{array}{c}28 \mathrm{~Gy} \text { in } 4 \\
\text { fractions }\end{array}$ & $\begin{array}{l}59 \% \text { in HDD group } \\
\text { were ambulatory } v s . \\
33 \% \text { in control group } \\
\text { at } 6 \text { months } \\
\text { posttreatment. }(p=0.05) \\
30 \% \text { in HDD group } \\
\text { were ambulatory } v s . \\
20 \% \text { in control group } \\
\text { at } 1 \text {-year } \\
\text { posttreatment. }(p=0.40)\end{array}$ & $\begin{array}{l}\text { Significant side-effects } \\
\text { in } 7 \% \text { of patients } \\
\text { (hypomania, psychosis, } \\
\text { perforate gastric ulcer } \\
\text { and, systemic } \\
\text { infection equally) }\end{array}$ \\
\hline $\begin{array}{l}\text { Heimdal K et al. } \\
(29), 1992\end{array}$ & $\begin{array}{l}\text { Prospective } \\
\text { study }\end{array}$ & 56 & $\begin{array}{c}100 \mathrm{mg} \text { IV bolus then } \\
96 \mathrm{mg} \text { IV ( } 24 \mathrm{mg} \text { QID) } \\
\text { vs. } 16 \mathrm{mg}(4 \mathrm{mg} \text { IV QID) } \\
\text { weaned over } 15 \text { days }\end{array}$ & $\begin{array}{l}\text { 30Gy in } 10 \\
\text { fractions }\end{array}$ & $\begin{array}{l}\text { No significant } \\
\text { difference regarding } \\
\text { ambulation rates } \\
\text { between groups. }\end{array}$ & $\begin{array}{c}\text { HDD group had } \\
8 \text { events in } 7 \text { patients } \\
\text { (4 serious GI) } \\
\text { LDD group had } \\
3 \text { events, (none serious) }\end{array}$ \\
\hline $\begin{array}{l}\text { Vecht CJ et al. } \\
(30), 1989\end{array}$ & $\begin{array}{l}\text { Retrospective } \\
\text { study }\end{array}$ & 37 & $\begin{array}{l}100 \mathrm{mg} \text { IV bolus } \\
v s .10 \mathrm{mg} \text { IV bolus } \\
\text { followed by } 16 \mathrm{mg} \\
(4 \mathrm{mg} \text { PO QID) }\end{array}$ & $\begin{array}{l}\text { 21-30 Gy in } \\
7-10 \text { fractions }\end{array}$ & $\begin{array}{c}\text { No significant } \\
\text { difference regarding } \\
\text { ambulation, pain, } \\
\text { or bladder function } \\
\text { after } 24 \mathrm{~h} \\
\text { between groups. }\end{array}$ & Not mentioned \\
\hline $\begin{array}{l}\text { Wong ML, et al. } \\
(35), 2014\end{array}$ & $\begin{array}{l}\text { Retrospective } \\
\text { study }\end{array}$ & 16 & $\begin{array}{c}\text { Not } \\
\text { mentioned }\end{array}$ & $\begin{array}{l}\text { Single-stage } \\
\text { posterolateral } \\
\text { transpedicular } \\
\text { corpectomy and } \\
\text { multisegmental } \\
\text { stabilization }\end{array}$ & $\begin{array}{c}\text { The average pain } \\
\text { score was reduced } \\
\text { from severe (VAS 9) } \\
\text { to mild (VAS 3.6) } \\
\text { after surgery. } \\
\text { Improvement of } \\
\text { neurological status } \\
\text { in } 90 \% \text { of patients. }\end{array}$ & $\begin{array}{c}\text { Dural tear and } \\
\text { spinal cord injury } \\
\text { could be potential } \\
\text { risks }\end{array}$ \\
\hline $\begin{array}{l}\text { Watanabe N et al. } \\
(41), 2016\end{array}$ & $\begin{array}{l}\text { Retrospective } \\
\text { study }\end{array}$ & 112 & $\begin{array}{c}\text { Not } \\
\text { mentioned }\end{array}$ & $\begin{array}{l}\text { Posterior surgical } \\
\text { procedure }\end{array}$ & $\begin{array}{l}84 \% \text { of ambulatory } \\
\text { before surgery } \\
\text { patients retained } \\
\text { ability to ambulate. } \\
20 \% \text { of nonambulatory } \\
\text { before surgery } \\
\text { patients regained the } \\
\text { ability to ambulate. } \\
\text { Average survival } \\
\text { period of } 12 \text { months } \\
\text { in both groups. } \\
\text { No association between } \\
\text { postoperative ambulatory } \\
\text { status and Tokuhashi score } \\
\text { or type of primary tumor. }\end{array}$ & $\begin{array}{c}\text { Not } \\
\text { mentioned }\end{array}$ \\
\hline $\begin{array}{l}\text { Greenberg HS } \\
\text { et al. }(74), 1980\end{array}$ & $\begin{array}{l}\text { Prospective } \\
\text { study }\end{array}$ & 83 & $\begin{array}{l}100 \mathrm{mg} \text { IV bolus then } \\
96 \mathrm{mg}(24 \mathrm{mg} \text { QID) } \\
\text { weaned over } 14 \text { days }\end{array}$ & $\begin{array}{l}5 \text { Gy*3 days, } \\
4 \text { days rest then } \\
3 \text { Gy*5 days }\end{array}$ & $\begin{array}{l}64 \% \text { experienced } \\
\text { substantial pain relief } \\
\text { one day following } \\
\text { steroid therapy. } \\
10 \% \text { had complete pain } \\
\text { relief following steroid } \\
\text { therapy only. }\end{array}$ & $\begin{array}{l}\text { Ruptured duodenal } \\
\text { ulcer in } 1.2 \% \\
\text { of patients } \\
\text { Hallucinations, } \\
\text { insomnia, } \\
\text { tremors, paresthesias, } \\
\text { variably }\end{array}$ \\
\hline $\begin{array}{l}\text { Fadul CE } \\
\text { et al. }(75), 1998\end{array}$ & $\begin{array}{l}\text { Retrospective } \\
\text { study }\end{array}$ & 226 & $\begin{array}{c}100 \mathrm{mg} \text { weaned } \\
\text { over } 21 \text { days } \\
\text { vs. } 16 \mathrm{mg} \text { weaned } \\
\text { over } 21 \text { days } \\
\text { versus }\end{array}$ & $\begin{array}{c}\text { Not } \\
\text { mentioned }\end{array}$ & $\begin{array}{c}\text { Not } \\
\text { mentioned }\end{array}$ & $\begin{array}{l}\text { HDD group had GI } \\
\text { bleeding in } 3.5 \% \text { of } \\
\text { patients and GI } \\
\text { perforations in } 2.7 \% \\
\text { of patients. }\end{array}$ \\
\hline
\end{tabular}


Table I. Continued

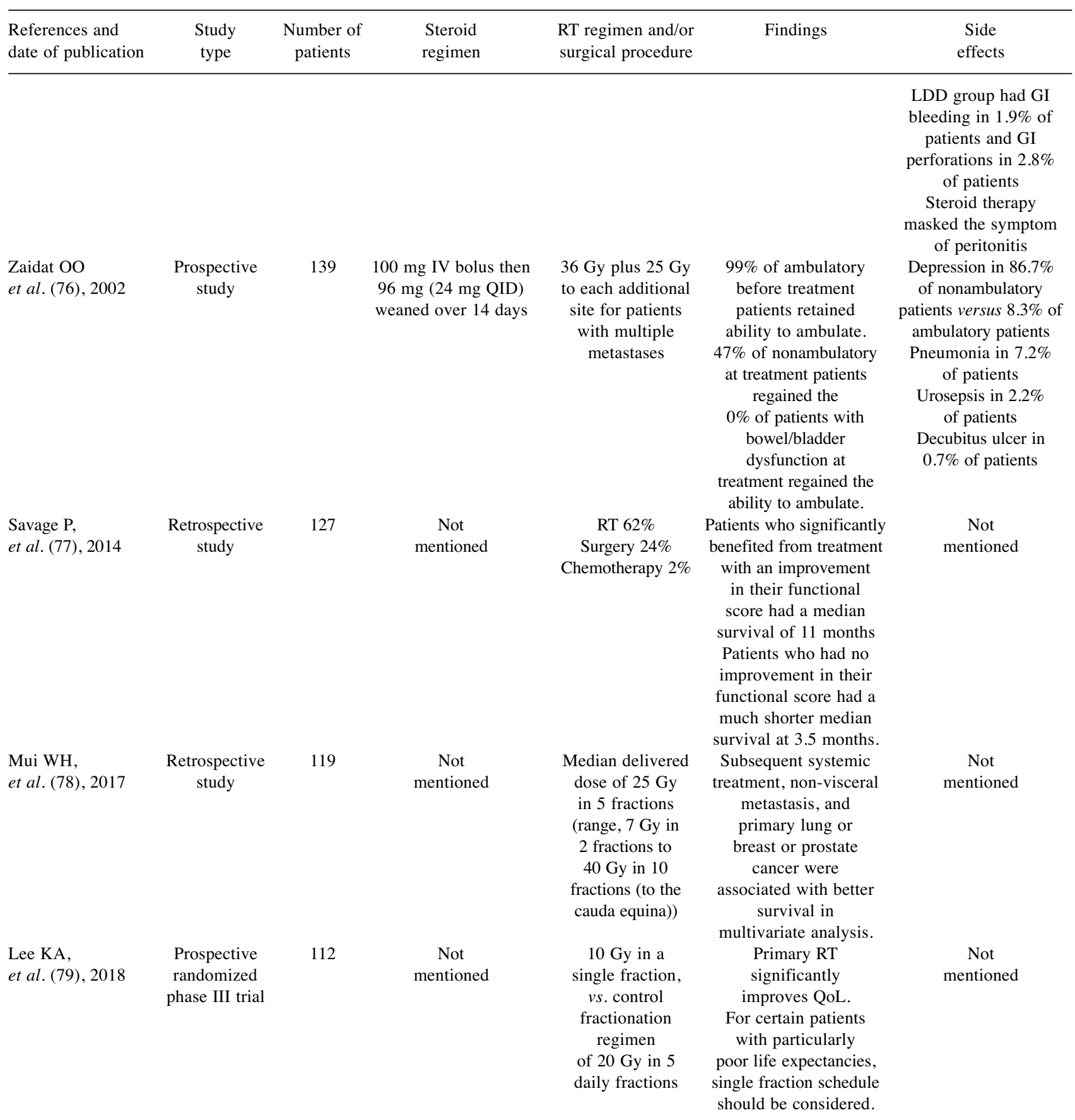

MSCC: Malignant spinal cord compression; RT: radiotherapy; IV: intravenous; QID: quater in die; HDD: high-dose dexamethasone; GI: gastrointestinal; LDD, low-dose dexamethasone; PO: per os; QoL: quality of life; VAS: visual analogue scale.

Corticosteroids. The initial modality is glucocorticoids. Loading dose of intravenous dexamethasone is followed by maintenance, administered either intravenously or orally. There is consensus that combination of steroids with RT is superior to RT alone (26). Corticosteroids reduce spinal cord vasogenic edema, and the secondary complication of reduced arterial flow and subsequent ischemia, infarction, and irreversible injury (13). This effect significantly improves or 
at least stabilizes neurological deficits while definitive treatment is initiated. Rapid improvement of motor function following initiation of steroids is a positive prognostic sign as it is associated with further recovery of strength after definitive treatment (27). Furthermore, they also provide analgesia and have direct cytotoxic effects on lymphomas, leukemias, melanomas, and even breast cancer $(13,24)$.

Steroids are most effective when administered immediately once the diagnosis of MSCC is confirmed, ideally within 12-hours of symptom onset. Definitive therapy with RT or surgery should be shortly implemented and steroids promptly weaned to reduce the incidence of side effects. This may increase the ambulatory capacity at 1 -year post treatment; nevertheless, there is no definitive effect on survival. Side effects from steroids include hyperglycemia, increased risk of infection, fluid retention, impaired wound healing, steroid myopathy, hypomania, psychosis, gastrointestinal hemorrhage, and perforated gastric ulcer requiring surgery $(24,27,28)$.

The initial dose and tapering schedule of steroids vary significantly. Their implementation in the neoadjuvant setting is based on the results of a single-blinded, randomized study from 1994 (27). Fifty-seven patients with MSCC were randomized to dexamethasone with a $96 \mathrm{mg}$ intravenous bolus followed by $24 \mathrm{mg}$ orally every 6 hours schedule with a taper over 10 days versus no dexamethasone. All patients were treated with RT, with a total dose of 28 Gy in seven daily fractions. The results showed that ambulatory function at 1 year was significantly higher in the arm with the steroids; nevertheless, median survival did not differ between the two groups at 6 months. Furthermore, lower doses of steroids for loading and maintenance have been shown equally efficacious and better tolerated than highdose. Indeed, no differences in ambulation have been described between a high-dose of $96 \mathrm{mg}$ dexamethasone loading dose, which was then tapered to zero over a 14-day period and, a low-dose of $16 \mathrm{mg} / \mathrm{day}$; though more serious events were more common in the high-dose group (29). Similarly, the report of a study in which therapy was initiated with a low-dose of bolus $10 \mathrm{mg}$ versus high-dose bolus of $100 \mathrm{mg}$, revealed undistinguished outcomes and improved safety profile between study arms (30). Both groups received daily dosage of $16 \mathrm{mg}$ for a week thereafter, followed by RT in 7-10 fractions of 3 Gy each.

There is a debate in terms of the optimal duration of steroid therapy, due to the fact that significant and undesirable toxicity from steroids has been demonstrated between 21 and 40 days following initiation (26). Steroids are bound to serum albumin and therefore hypoalbuminemia may lead to higher concentrations of free steroid molecules. Indeed, data from case series have highlighted that patients who did not suffer from steroid toxicity displayed unchanged albumin levels before and after the treatment (26).
Surgery. Surgery is indicated in patients with MSCC, spinal instability, or failed prior RT, with the prospect of preservation of neurological function, pain control, and mechanical stability of the weakened vertebral column (13, 28). It has been demonstrated that the level of preoperative paralysis before surgery is the main determinant for postoperative gait function $(31,32)$. Given the dismal prognosis in many of MSCC patients, the decision for surgery is often controversial. Surgical decompression followed by RT preserved ambulation for a prolonged period of time as compared to RT alone in the subset of less radiosensitive tumor types $(13,20,33)$. A meta-analysis demonstrated regaining ambulatory function, and improved pain control with a difference in 1-year survival of $41 \%$ versus $24 \%$ in favor of surgery followed by RT versus RT alone (34). However, patients who are not expected to survive more than 3-6 months are not candidates for this therapeutic management. Traditionally, patients with MSCC were treated with laminectomy alone in order to achieve decompression of neural elements (20). However, a randomized non-blinded trial, has demonstrated superiority of surgery plus RT over RT alone (18). Spinal stabilization was performed in this trial, which might have contributed to the better surgical results than laminectomy alone, as shown in previous studies. Potential complications of surgery include respiratory complications, thromboembolism, CSF leak, wound infection, and deterioration of neurological symptoms due to vasogenic edema (28).

Determination of the most appropriate surgical approach remains a challenge and, depends on the location of the tumor within the vertebral body (13). Posterior decompressive laminectomy, consisting of removal of the posterior elements of the spinal column, was the treatment of MSCC, prior to development of external-beam RT (20). Anterior spinal decompression through transthoracic or retroperitoneal approach permits direct removal of ventral compressive tumours. Posterolateral approach often sacrifices segmental nerve roots for the placement of cages. In a retrospective study, ventral column was reconstructed with expendable cages, resulting in restoration of vertebral height (35). This technique endorsed preservation of all nerve roots, thus making it suitable for the entire thoracolumbar spine. The neurological status was improved in $90 \%$ of patients in this series, and the pain due to spinal metastases, was reduced significantly postoperatively. Overall, laminectomy has demonstrated efficacy only in cases of posterior cord compression. Several studies revealed that vertebrectomy, through posterolateral, or anterior approaches, is more beneficial for the improvement of both ambulatory capacity and pain control than laminectomy (36). On the other hand, local tumour extension in the thoracic or peritoneal cavity affects the viability of the anterior approach, and additional posterior stabilization may be 
required to reinforce the anterior construct. Advanced techniques, are currently developed to provide optimal decompression with limited RT damage to the spinal cord. This is the case of the separation surgery, in which a portion of the tumor is removed, so as to create a margin surrounding the spinal cord for application of RT $(33,37)$.

Prognostic scoring systems, have been developed in order to predict patients' overall survival and guide therapeutic approach $(13,33)$. Tokuhashi scoring system, accounts for factors associated with both the spine and the primary tumour type and is used in clinical practice (38), to predict survival of patients with spinal metastases. However, primary cancer site may not always be known prior to surgery, and thus, Tokuhashi score is not always applicable for the determination of the feasibility of surgery. In a study by Park et al., preoperative Tokuhashi score was significantly associated with longer overall survival, but it was not prognostic of postoperative ambulation (39). On the other hand, Moon et al. demonstrated that the system was neither a prognostic predictor for ambulatory function, nor for survival (40). A retrospective analysis of MSCC patients treated with surgery revealed that they should ideally be operated before their American Spinal Injury Association (ASIA) Impairment Scale grades falls below C (41).

Radiation therapy. QoL indicators at the end of life have shown that aggressive cancer treatment could represent an indicator of poor-quality care (42). With this regard, palliative RT alone is a reasonable treatment of choice for patients with an expected limited survival, probably of less than 6 months, so as to avoid unnecessary surgical procedures $(7,37,43,44)$. Pre-radiation neurological status represents the most important predictive factor of outcome $(13,45)$, following by Karnofsky score, type of primary malignancy with focus on radiosensitivity, and systemic tumor burden, as well as extent of anatomic compression of the thecal sac, duration of motor deficits, and interval between tumor diagnosis and the potential MSCC. Radiation should be delivered both to the involved segment and one uninvolved rostral and caudal vertebral body, in an effort to maximize dose to the tumor bed and at the same time to prevent further dissemination to other vertebral bodies (13).

Overall, patients with shorter life expectancies are offered higher doses of radiation in abbreviated courses, while those with less extensive disease are managed with lower doses over a prolonged period of time (20). Maranzano et al., have conducted a prospective randomised study in poor prognosis MSCC patients, defined as those having either unfavorable histologies or favorable in the presence of motor or sphincter dysfunction and/or low performance status (37). They demonstrated that a split course of 30 Gy over 2 weeks, was similar to short-course RT, in terms of pain control, maintenance of ambulation, and preservation of bladder function (13, 20, 37). Furthermore, Rades et al., investigated MSCC patients treated by short-course RT and namely, one dose of 8 Gy in 1 day, or five doses of 4 Gy in 1 week, versus those who underwent long-course RT with available options of 10 doses of $3 \mathrm{~Gy}$ in 2 weeks, 15 doses of 2.5 Gy in 3 weeks, and 20 doses of 2 Gy in 4 weeks (46). The observed outcomes in terms of post-treatment ambulatory rates and motor function improvements were similar between all cohorts. As such, a single dose of $8 \mathrm{~Gy}$ in one fraction is a reasonable approach of palliative treatment for the subset of patients with a short life expectancy whereas, schedules such as $30 \mathrm{~Gy}$ in 10 fractions to $40 \mathrm{~Gy}$ in 20 fractions, should be used for those with expected long-term survival $(33,37)$. Essentially, doses of 30-40 Gy in 10 fractions are enough to provide durable disease control $(33,47)$. Similarly, a review of 26 studies of phase II and III trials concluded that shortcourse RT is administered to patients with MSCC and short life expectancy (Tokuhashi score 0-8) whereas, long-course RT to those with inoperable MSCC and expected long-term survival (Tokuhashi score 9-15) (36). Otherwise, Sze et al. found no difference in pain relief between single- and multifraction RT (48). Finally, no difference in the primary end-point was demonstrated by both SCORE-2 and the SCORAD III RT schedules comparing a multifractionated schedule with fewer or a single fraction $(49,50)$.

RT may be related to adverse effects including gastrointestinal toxicity, mucositis, bone marrow suppression and several subtypes of radiation-induced myelopathy. Acute transient radiation myelopathy is the most common subtype that presents 1-29 months after completion of RT and is developed as a result of demyelination of the dorsal columns. Clinical manifestations include Lhermitte's sign in the absence of neurological changes on examination, and symptoms may resolve within weeks or even months (24). Chronic progressive radiation myelopathy occurs 9-15 months following RT and has been reported in $1-5 \%$ of patients who reach 1-year survival, presenting with ascending weakness, and diminished sensation (19, 24). Acute complete radiation myelopathy is related to radiation induced vascular damage resulting in spinal cord infarction, whereas lower motor neuron disease occurs due to anterior horn cell damage (24).

Stereotactic body $R T$ and stereotactic radiosurgery. The recent technological advances in RT have enabled the implementation of stereotactic body RT and SRS to patients with malignancies. Stereotactic body RT typically involves the delivery of one or a few large dose fractions of 8 to 30 Gy per fraction under imaging guidance (13). The radiation is conformed specifically to the shape of the tumor $(33,51,52)$. As such, it achieves the delivery of almost twice the amount of radiation as conventional external beam therapy, which is usually $30 \mathrm{~Gy}$ in 10 fractions (53). The 
primary indication for stereotactic body RT is painful spine metastases as described in the largest report by Gerszten et $a l$, in which the achieved long-term tumor control and pain improvement reached $90 \%$ and $86 \%$, respectively (54). Several other series demonstrated similar outcomes with both satisfactory tumor control and pain relief (55-57). Stereotactic body RT has been tested against conventional RT in the setting of recurrence, which is particularly important since up to $25 \%$ of patients develop recurrent spinal cord compression after front-line RT (58). Furthermore, stereotactic body RT may be implemented in radioresistant tumors (13). However, the American Society for Radiation Oncology Guidelines recommends that patients with poor performance status should not be managed with Stereotactic body RT (51).

Currently, there is low level of evidence for the superiority of SRS over conventional fractionated radiation or decompressive surgery (59). In a cohort of 62 patients with MSCC, treated with a single fraction SRS of 14-20 Gy, improvement of the neurological function was achieved in $81 \%$ of cases $(60)$.

Overall, SRS and stereotactic body RT of metastases in the spine, are considerably safe with reported low risk of grade 3 toxicity, including nausea, vomiting, diarrhea, fatigue, trismus and pain $(55,56)$. Their implementation in the treatment of MSCC is not clearly defined.

Systemic therapy. There is lack of data on the effect of systemic therapy on survival of MSCC patients treated with palliative RT. Rades et al., reported a trend towards improved local control, and significant higher survival rates at 6 and 12 months, with the initiation of bisphosphonates in univariate analysis (46). However, this could be attributed to the fact that bisphosphonates, are effective in reducing the risk of pathological fractures, relieving pain and reducing malignancy associated hypercalcemia in cancers that produce osteolytic metastases (61).

Chemotherapy is considered for highly chemo-sensitive tumors. However, in the majority of the patients, its role is limited due to slow and unpredictable response of the tumor and the urgent requirement of spinal cord decompression $(28,61)$. Currently, there is strong evidence that targeted therapy has prolonged the median survival of metastatic nonsmall lung cancer patients (62). Indeed, tyrosine kinase inhibitors have further improved the treatment response rates and the median progressive-free survival of patients harboring epidermal growth factor receptor or anaplastic lymphoma kinase mutations $(63,64)$. Furthermore, advances in understanding T-cell immune checkpoints and the immune recognition in a wide range of malignancies as highly immunogenic, helped to identify immunotherapies as additional therapeutic tools (65-68). It is believed that MSCC patients with dismal prognosis, and a reasonable for the implementation of effective systemic therapy performance status, would have higher likelihood of prolonged survival. As such, local control is hugely important and, multi-Fr or long-course RT is preferred $(46,69,70)$. On the other hand, patients included in Tokuhashi group 1, who lack capacity for systemic treatment options, single-Fr treatment is a reasonable approach.

Rehabilitation. Mechanism of injury and medical comorbidities of MSCC may differ from traumatic injuries; however, similar principles of neuro-rehabilitation can be applied, that aim at pain relief, prevention of further complications, enhancement of functional independence, and improvement of QoL, and psychology (71). A meta-analysis of 38 studies of MSCC paraplegic patients demonstrates oneyear survival rates ranging from 12 to $58 \%$, with median survival between 2.4 and 30 months (72). The optimal rehabilitation service delivery, is affected by personal and financial factors. In Ontario, inpatient rehabilitation represents the largest short-term system cost driver in the traumatic spinal cord injury. Non-traumatic spinal cord injury prevalence is likely considerable, even though has not been reported (73).

Clarification of the etiology of pain is crucial for the determination of the therapeutic approach. Postural bracing can be achieved through custom and commercial orthotics and can accommodate all regions of the spine. The least restrictive brace appropriate should be chosen in every individualized case for the optimal stability and prevention of further muscle weakness. Pain control may be achieved with the use of steroids, non-steroidal anti-inflammatories, anticonvulsants, tricyclic antidepressants and opioids. Potential side-effects, should be managed appropriately. Physical modalities such as heat, cold, ultrasound and electrical stimulation may be included into pain management. However, their application may promote increased blood flow, that could be involved in disease dissemination (28). Spasticity which is a common complication of upper motor neuron lesions may be managed with passive stretching exercises, stretching splints and medications including baclofen, tizanidine and benzodiazepines. In terms of bladder dysfunction, programs are established individually on the basis of the findings of neurological examination, and urodynamic studies. Intermittent catheterization or indwelling catheters can be implemented for either upper or lower motor neuron bladder patterns, whereas, anticholinergic agents are a choice for patients with upper motor neuron patterns. With regards to bowel dysfunction, stool softeners, oral stimulants and contact irritants are indicated for upper motor neuron bowel patterns whereas, for lower patterns oral bulk forming agents and manual removal of stool can be offered. Paraplegia, bowel and bladder dysfunction, as well as malnutrition can increase risk for skin breakdown. Patients should be educated about techniques for pressure relief, skin hygiene and importance of nutrition (28). 


\section{Conclusion}

MSCC represents an oncologic emergency and clinicians should be aware of the potential long-term neurological impact that requires urgent diagnosis and treatment. Due to the heterogeneity of patients, the management of those without a current cancer diagnosis who present primarily to primary care with back pain is still challenging.

Steroid therapy is administered immediately after the establishment of diagnosis, followed by definitive treatment; nevertheless, there is no determined survival benefit. Dexamethasone is the steroid agent of choice. Lower doses have been associated with better tolerance than higher Steroids should be rapidly weaned to minimize the incidence of side-effects. Patients who are found to have spinal instability should be referred for surgical evaluation followed by adjuvant RT. Those with poor performance status or not surgical candidates should be evaluated for RT. A singlefraction schedule is reasonable for patients with poor life expectancies. The knowledge of rehabilitation principles and practices to this patient population is also important.

Future research should be focused on the identification of patients, disease, and treatment-related factors that result in improved outcomes. A randomized controlled study design is extremely demanding, due to multiple tumor types, and the unique anatomy of each compressive mass.

\section{Conflicts of Interest}

The Authors declare no conflict of interest.

\section{References}

1 Böhm P and Huber J: The surgical treatment of bony metastases of the spine and limbs. J Bone Joint Surg Br 84(4): 521-529, 2002.

2 Drudge-Coates L and Rajbabu K: Diagnosis and management of malignant spinal cord compression: part 1. Int J Palliat Nurs 14(3): 110-116, 2008.

3 Loblaw DA and Laperriere NJ: Emergency treatment of malignant extradural spinal cord compression: an evidence-based guideline. J Clin Oncol 16(4): 1613-1624, 1998.

4 White BD, Stirling AJ, Paterson E, Asquith-Coe K, Melder A and Guideline Development Group: Diagnosis and management of patients at risk of or with metastatic spinal cord compression: summary of NICE guidance. BMJ 337: a2538, 2008.

5 Posner J: Spinal metastases. In: Neurologic complications of cancer. Philadelphia, FA Davis Company, pp. 111-142, 1995.

6 Rades D, Rudat V, Veninga T, Stalpers LJ, Basic H, Karstens JH, Hoskin PJ and Schild SE: A score predicting posttreatment ambulatory status in patients irradiated for metastatic spinal cord compression. Int J Radiat Oncol Biol Phys 72(3): 905-908, 2008.

7 Rades D, Fehlauer F, Schulte R, Veninga T, Stalpers LJ, Basic H, Bajrovic A, Hoskin PJ, Tribius S, Wildfang I, Rudat V, Engenhart-Cabilic R, Karstens JH, Alberti W, Dunst J and Schild SE: Prognostic factors for local control and survival after radiotherapy of metastatic spinal cord compression. J Clin Oncol 24(21): 3388-3393, 2006.
8 Tokuhashi Y, Matsuzaki H, Toriyama S, Kawano H and Ohsaka S: Scoring system for the preoperative evaluation of metastatic spine tumor prognosis. Spine (Phila Pa 1976) 15(11): 1110-1113, 1990.

9 Tomita K, Kawahara N, Kobayashi T, Yoshida A, Murakami H and Akamaru T: Surgical strategy for spinal metastases. Spine (Phila Pa 1976) 26(3): 298-306, 2001.

10 Akeyson EW and McCutcheon IE: Single-stage posterior vertebrectomy and replacement combined with posterior instrumentation for spinal metastasis. J Neurosurg 85(2): 211-220, 1996.

11 Cahill DW and Kumar R: Palliative subtotal vertebrectomy with anterior and posterior reconstruction via a single posterior approach. J Neurosurg 90(1): 42-47, 1999.

12 Kwok Y, Regine WF and Patchell RA: Radiation therapy alone for spinal cord compression: time to improve upon a relatively ineffective status quo. J Clin Oncol 23(15): 3308-3310, 2005.

13 Ribas ES and Schiff D: Spinal cord compression. Curr Treat Options Neurol 14(4): 391-401, 2012.

14 Loblaw DA, Laperriere NJ and Mackillop WJ: A populationbased study of malignant spinal cord compression in Ontario. Clin Oncol (R Coll Radiol) 15(4): 211-217, 2003.

15 Levack P, Graham J, Collie D, Grant R, Kidd J, Kunkler I, Gibson A, Hurman D, McMillan N, Rampling R, Slider L, Statham P, Summers D and Scottish Cord Compression Study Group: Don't wait for a sensory level - listen to the symptoms: a prospective audit of the delays in diagnosis of malignant cord compression. Clin Oncol (R Coll Radiol) 14(6): 472-480, 2002.

16 Perrin RG and Laxton AW: Metastatic spine disease: epidemiology, pathophysiology, and evaluation of patients. Neurosurg Clin N Am 15(4): 365-373, 2004.

17 Sciubba DM and Gokaslan ZL: Diagnosis and management of metastatic spine disease. Surg Oncol 15(3): 141-151, 2006.

18 Patchell RA, Tibbs PA, Regine WF, Payne R, Saris S, Kryscio RJ, Mohiuddin M and Young B: Direct decompressive surgical resection in the treatment of spinal cord compression caused by metastatic cancer: a randomised trial. Lancet 366(9486): 643648, 2005.

19 Schiff D: Spinal cord compression. Neurol Clin 21(1): 67-86, 2003.

20 Cole JS and Patchell RA: Metastatic epidural spinal cord compression. Lancet Neurol 7(5): 459-466, 2008.

21 Buhmann Kirchhoff S, Becker C, Duerr HR, Reiser M and BaurMelnyk A: Detection of osseous metastases of the spine: comparison of high resolution multi-detector-CT with MRI. Eur J Radiol 69(3): 567-573, 2009.

22 McCurdy MT and Shanholtz CB: Oncologic emergencies. Crit Care Med 40(7): 2212-2222, 2012.

23 Kim DHCU: Neurological presentation of spinal tumors. In: Tumors of the Spine Kim S and Bilsky M (eds.). Philadelphia, PA: Saunders Elsevier, pp. 115-121, 2008.

24 Hammack JE: Spinal cord disease in patients with cancer. Continuum (Minneap Minn) 18(2): 312-327, 2012.

25 Helweg-Larsen S and Sørensen PS: Symptoms and signs in metastatic spinal cord compression: a study of progression from first symptom until diagnosis in 153 patients. Eur J Cancer 30A(3): 396-398, 1994.

26 Kumar A, Weber MH, Gokaslan Z, Wolinsky JP, Schmidt M, Rhines L, Fehlings MG, Laufer I, Sciubba DM, Clarke MJ, Sundaresan N, Verlaan JJ, Sahgal A, Chou D and Fisher CG: Metastatic spinal cord compression and steroid treatment: A systematic review. Clin Spine Surg 30(4): 156-163, 2017. 
27 Sørensen S, Helweg-Larsen S, Mouridsen H and Hansen HH: Effect of high-dose dexamethasone in carcinomatous metastatic spinal cord compression treated with radiotherapy: A randomised trial. Eur J Cancer 30A(1): 22-27, 1994.

28 Raj VS and Lofton L: Rehabilitation and treatment of spinal cord tumors. J Spinal Cord Med 36(1): 4-11, 2013.

29 Heimdal K, Hirschberg H, Sletteb $\varnothing$ H, Watne K and Nome O: High incidence of serious side effects of high-dose dexamethasone treatment in patients with epidural spinal cord compression. J Neurooncol 12(2): 141-144, 1992.

30 Vecht CJ, Haaxma-Reiche H, van Putten WL, de Visser M, Vries EP and Twijnstra A: Initial bolus of conventional versus highdose dexamethasone in metastatic spinal cord compression. Neurology 39(9): 1255-1257, 1989.

31 Chaichana KL, Woodworth GF, Sciubba DM, McGirt MJ, Witham TJ, Bydon A, Wolinsky JP and Gokaslan Z: Predictors of ambulatory function after decompressive surgery for metastatic epidural spinal cord compression. Neurosurgery 62(3): 683-692, 2008.

32 Helweg-Larsen S, Sørensen PS and Kreiner S: Prognostic factors in metastatic spinal cord compression: a prospective study using multivariate analysis of variables influencing survival and gait function in 153 patients. Int J Radiat Oncol Biol Phys 46(5): 1163$1169,2000$.

33 Ropper AE and Ropper AH: Acute spinal cord compression. N Engl J Med 376(14): 1358-1369, 2017.

34 Klimo P Jr., Thompson CJ, Kestle JR and Schmidt MH: A metaanalysis of surgery versus conventional radiotherapy for the treatment of metastatic spinal epidural disease. Neuro Oncol 7(1): 64-76, 2005.

35 Wong ML, Lau HC and Kaye AH: The management of malignant spinal cord compression: a modified technique of spinal reconstruction. Neurol Res 36(6): 544-549, 2014.

36 L'Espérance S, Vincent F, Gaudreault M, Ouellet JA, Li M, Tosikyan A, Goulet $\mathrm{S}$ and Comité de l'évolution des pratiques en oncologie: Treatment of metastatic spinal cord compression: cepo review and clinical recommendations. Curr Oncol 19(6): 3478-3490, 2012.

37 Maranzano E, Bellavita R, Rossi R, De Angelis V, Frattegiani A, Bagnoli R, Mignogna M, Beneventi S, Lupattelli M, Ponticelli P, Biti GP and Latini P: Short-course versus split-course radiotherapy in metastatic spinal cord compression: results of a phase III, randomized, multicenter trial. J Clin Oncol 23(15): 3358-3365, 2005

38 Tokuhashi Y, Matsuzaki H, Oda H, Oshima M and Ryu J: A revised scoring system for preoperative evaluation of metastatic spine tumor prognosis. Spine (Phila Pa 1976) 30(19): 2186-2191, 2005.

39 Park JH, Rhim SC and Jeon SR: Efficacy of decompression and fixation for metastatic spinal cord compression: analysis of factors prognostic for survival and postoperative ambulation. J Korean Neurosurg Soc 50(5): 434-440, 2011.

40 Moon KY, Chung CK, Jahng TA, Kim HJ and Kim CH: Postoperative survival and ambulatory outcome in metastatic spinal tumors: prognostic factor analysis. J Korean Neurosurg Soc 50(3): 216-223, 2011

41 Watanabe N, Sugimoto Y, Tanaka M, Mazaki T, Arataki S, Takigawa T, Kataoka M, Kunisada T and Ozaki T: Neurological recovery after posterior spinal surgery in patients with metastatic epidural spinal cord compression. Acta Med Okayama 70(6): 449-453, 2016.
42 Earle CC, Landrum MB, Souza JM, Neville BA, Weeks JC and Ayanian JZ: Aggressiveness of cancer care near the end of life: is it a quality-of-care issue? J Clin Oncol 26(23): 3860-3866, 2008.

43 Hoskin PJ, Grover A and Bhana R: Metastatic spinal cord compression: radiotherapy outcome and dose fractionation. Radiother Oncol 68(2): 175-180, 2003.

44 Choi D, Crockard A, Bunger C, Harms J, Kawahara N, Mazel C, Melcher R, Tomita K and Global Spine Tumor Study Group: Review of metastatic spine tumour classification and indications for surgery: the consensus statement of the Global Spine Tumour Study Group. Eur Spine J 19(2): 215-222, 2010.

45 Rades D, Douglas S, Veninga T, Stalpers LJ, Hoskin PJ, Bajrovic A, Adamietz IA, Basic H, Dunst J and Schild SE: Validation and simplification of a score predicting survival in patients irradiated for metastatic spinal cord compression. Cancer 116(15): 3670-3673, 2010.

46 Rades D, Lange M, Veninga T, Stalpers LJ, Bajrovic A, Adamietz IA, Rudat $\mathrm{V}$ and Schild SE: Final results of a prospective study comparing the local control of short-course and long-course radiotherapy for metastatic spinal cord compression. Int J Radiat Oncol Biol Phys 79(2): 524-530, 2011.

47 Rades D, Stalpers LJ, Veninga T, Schulte R, Hoskin PJ, Obralic N, Bajrovic A, Rudat V, Schwarz R, Hulshof MC, Poortmans P and Schild SE: Evaluation of five radiation schedules and prognostic factors for metastatic spinal cord compression. J Clin Oncol 23(15): 3366-3375, 2005.

48 Sze WM, Shelley M, Held I and Mason M: Palliation of metastatic bone pain: single fraction versus multifraction radiotherapy - a systematic review of the randomised trials. Cochrane Database Syst Rev (2): CD004721, 2004.

49 Rades D, Šegedin B, Conde-Moreno AJ, Garcia R, Perpar A, Metz M, Badakhshi H, Schreiber A, Nitsche M, Hipp P, Schulze W, Adamietz IA, Norkus D, Rudat V, Cacicedo J and Schild SE: Radiotherapy with 4 Gy $\times 5$ versus 3 Gy $\times 10$ for metastatic epidural spinal cord compression: Final results of the SCORE-2 trial (ARO 2009/01). J Clin Oncol 34(6): 597-602, 2016.

50 Hoskin P, Misra V, Hopkins K, Holt T, Brown G, Arnott S, Sharon Shibu TS, Reczko K, Beare S, Lopes A and Forsyth S: SCORAD III: randomized noninferiority phase III trial of singledose radiotherapy (RT) compared to multifraction RT in patients (pts) with metastatic spinal canal compression (SCC). J Clin Oncol 35(18): LBA10004, 2017.

51 Hashmi A, Guckenberger M, Kersh R, Gerszten PC, Mantel F, Grills IS, Flickinger JC, Shin JH, Fahim DK, Winey B, Oh K, John Cho BC, Létourneau D, Sheehan J and Sahgal A: Re-irradiation stereotactic body radiotherapy for spinal metastases: a multiinstitutional outcome analysis. J Neurosurg Spine 25(5): 646-653, 2016.

52 Chow E, van der Linden YM, Roos D, Hartsell WF, Hoskin P, Wu JS, Brundage MD, Nabid A, Tissing-Tan CJ, Oei B, Babington S, Demas WF, Wilson CF, Meyer RM, Chen BE and Wong RK: Single versus multiple fractions of repeat radiation for painful bone metastases: a randomised, controlled, noninferiority trial. Lancet Oncol 15(2): 164-171, 2014.

53 Jabehdar Maralani P, Lo SS, Redmond K, Soliman H, Myrehaug S, Husain ZA, Heyn C, Kapadia A, Chan A and Sahgal A: Spinal metastases: multimodality imaging in diagnosis and stereotactic body radiation therapy planning. Future Oncol 13(1): 77-91, 2017.

54 Gerszten PC, Burton SA, Ozhasoglu C and Welch WC: Radiosurgery for spinal metastases: clinical experience in 500 
cases from a single institution. Spine (Phila Pa 1976) 32(2): 193199, 2007.

55 Wang XS, Rhines LD, Shiu AS, Yang JN, Selek U, Gning I, Liu P, Allen PK, Azeem SS, Brown PD, Sharp HJ, Weksberg DC, Cleeland CS and Chang EL: Stereotactic body radiation therapy for management of spinal metastases in patients without spinal cord compression: a phase 1-2 trial. Lancet Oncol 13(4): 395402, 2012.

56 Garg AK, Shiu AS, Yang J, Wang XS, Allen P, Brown BW, Grossman P, Frija EK, McAleer MF, Azeem S, Brown PD, Rhines LD and Chang EL: Phase $1 / 2$ trial of single-session stereotactic body radiotherapy for previously unirradiated spinal metastases. Cancer 118(20): 5069-5077, 2012.

57 Ahmed KA, Stauder MC, Miller RC, Bauer HJ, Rose PS, Olivier KR, Brown PD, Brinkmann DH and Laack NN: Stereotactic body radiation therapy in spinal metastases. Int $\mathrm{J}$ Radiat Oncol Biol Phys 82(5): e803-809, 2012.

58 Prasad D and Schiff D: Malignant spinal-cord compression. Lancet Oncol 6(1): 15-24, 2005.

59 Bate BG, Khan NR, Kimball BY, Gabrick K and Weaver J: Stereotactic radiosurgery for spinal metastases with or without separation surgery. J Neurosurg Spine 22(4): 409-415, 2015.

60 Ryu S, Rock J, Jain R, Lu M, Anderson J, Jin JY, Rosenblum M, Movsas B and Kim JH: Radiosurgical decompression of metastatic epidural compression. Cancer 116(9): 2250-2257, 2010.

61 Sciubba DM, Petteys RJ, Dekutoski MB, Fisher CG, Fehlings MG, Ondra SL, Rhines LD and Gokaslan ZL: Diagnosis and management of metastatic spine disease. A review. J Neurosurg Spine 13(1): 94-108, 2010.

62 Sandler A, Gray R, Perry MC, Brahmer J, Schiller JH, Dowlati A, Lilenbaum R and Johnson DH: Paclitaxel-carboplatin alone or with bevacizumab for non-small-cell lung cancer. N Engl J Med 355(24): 2542-2550, 2006.

63 Greenhalgh J, Dwan K, Boland A, Bates V, Vecchio F, Dundar Y, Jain P and Green JA: First-line treatment of advanced epidermal growth factor receptor (EGFR) mutation positive nonsquamous non-small cell lung cancer. Cochrane Database Syst Rev (5): CD010383, 2016

64 Solomon BJ, Mok T, Kim DW, Wu YL, Nakagawa K, Mekhail T, Felip E, Cappuzzo F, Paolini J, Usari T, Iyer S, Reisman A, Wilner KD, Tursi J, Blackhall $\mathrm{F}$ and PROFILE 1014 Investigators: First-line crizotinib versus chemotherapy in ALKpositive lung cancer. N Engl J Med 371(23): 2167-2177, 2014.

65 Ugurel S, Röhmel J, Ascierto PA, Flaherty KT, Grob JJ, Hauschild A, Larkin J, Long GV, Lorigan P, McArthur GA, Ribas A, Robert C, Schadendorf D and Garbe C: Survival of patients with advanced metastatic melanoma: The impact of novel therapies. Eur J Cancer 53: 125-134, 2016.

66 Ribas A, Puzanov I, Dummer R, Schadendorf D, Hamid O, Robert C, Hodi FS, Schachter J, Pavlick AC, Lewis KD, Cranmer LD, Blank CU, O'Day SJ, Ascierto PA, Salama AK, Margolin KA, Loquai C, Eigentler TK, Gangadhar TC, Carlino MS, Agarwala SS, Moschos SJ, Sosman JA, Goldinger SM, Shapira-Frommer R, Gonzalez R, Kirkwood JM, Wolchok JD, Eggermont A, Li XN, Zhou W, Zernhelt AM, Lis J, Ebbinghaus S, Kang SP and Daud A: Pembrolizumab versus investigator-choice chemotherapy for ipilimumab-refractory melanoma (KEYNOTE-002): A randomised, controlled, phase 2 trial. Lancet Oncol 16(8): 908-918, 2015.

67 Borghaei H, Paz-Ares L, Horn L, Spigel DR, Steins M, Ready NE, Chow LQ, Vokes EE, Felip E, Holgado E, Barlesi F, Kohlhäufl M,
Arrieta O, Burgio MA, Fayette J, Lena H, Poddubskaya E, Gerber DE, Gettinger SN, Rudin CM, Rizvi N, Crinò L, Blumenschein GR Jr., Antonia SJ, Dorange C, Harbison CT, Graf Finckenstein F and Brahmer JR: Nivolumab versus docetaxel in advanced nonsquamous non-small-cell lung cancer. N Engl J Med 373(17): 1627-1639, 2015.

68 Motzer RJ, Escudier B, McDermott DF, George S, Hammers HJ, Srinivas S, Tykodi SS, Sosman JA, Procopio G, Plimack ER, Castellano D, Choueiri TK, Gurney H, Donskov F, Bono P, Wagstaff J, Gauler TC, Ueda T, Tomita Y, Schutz FA, Kollmannsberger C, Larkin J, Ravaud A, Simon JS, Xu LA, Waxman IM and Sharma P; CheckMate 025 Investigators: Nivolumab versus everolimus in advanced renal-cell carcinoma. N Engl J Med 373(19): 1803-1813, 2015.

69 George R, Jeba J, Ramkumar G, Chacko AG and Tharyan P: Interventions for the treatment of metastatic extradural spinal cord compression in adults. Cochrane Database Syst Rev (9): CD006716, 2015.

70 Lam TC, Uno H, Krishnan M, Lutz S, Groff M, Cheney M and Balboni T: Adverse outcomes after palliative radiation therapy for uncomplicated spine metastases: Role of spinal instability and single-fraction radiation therapy. Int $\mathrm{J}$ Radiat Oncol Biol Phys 93(2): 373-381, 2015.

71 Kirshblum S, O'Dell MW, Ho C and Barr K: Rehabilitation of persons with central nervous system tumors. Cancer 92(4): 1029-1038, 2001.

72 Fattal C, Fabbro M, Gelis A and Bauchet L: Metastatic paraplegia and vital prognosis: perspectives and limitations for rehabilitation care. Part 1. Arch Phys Med Rehabil 92(1): 125-133, 2011.

73 Munce SE, Wodchis WP, Guilcher SJ, Couris CM, Verrier M, Fung K, Craven BC and Jaglal SB: Direct costs of adult traumatic spinal cord injury in Ontario. Spinal Cord 51(1): 64-69, 2013.

74 Greenberg HS, Kim JH and Posner JB: Epidural spinal cord compression from metastatic tumor: results with a new treatment protocol. Ann Neurol 8(4): 361-366, 1980.

75 Fadul CE, Lemann W, Thaler HT and Posner JB: Perforation of the gastrointestinal tract in patients receiving steroids for neurologic disease. Neurology 38(3): 348-352, 1988.

76 Zaidat OO and Ruff RL: Treatment of spinal epidural metastasis improves patient survival and functional state. Neurology 58(9): 1360-1366, 2002.

77 Savage P, Sharkey R, Kua T, Schofield L, Richardson D, Panchmatia N, Papanastasopoulos P, Williams M, Falconer A, Power D, Arnold F and Ulbricht C: Malignant spinal cord compression: NICE guidance, improvements and challenges. QJM 107(4): 277-282, 2014.

78 Mui WH, Lam TC, Wong FCS and Sze WK: Survival analysis of malignant epidural spinal cord compression after palliative radiotherapy using Tokuhashi scoring system and the impact of systemic therapy. Ann Palliat Med 6(2): S132-S139, 2017.

79 Lee KA, Dunne M, Small C, Kelly PJ, McArdle O, O'Sullivan J, Hacking D, Pomeroy M, Armstrong J, Moriarty M, ClaytonLea A, Parker I, Collins CD and Thirion P: (ICORG 05-03): prospective randomized non-inferiority phase III trial comparing two radiation schedules in malignant spinal cord compression (not proceeding with surgical decompression); the quality of life analysis. Acta Oncol 8: 1-8, 2018.

Received July 5, 2018

Revised July 19, 2018

Accepted July 23, 2018 